\title{
KEDUDUKAN HUKUM ADAT DALAM ERA REFORMASI
}

\author{
Abdul Mukmin \\ Alumni Fakultas Hukum Universitas Widya Gama Mahakam Samarinda \\ ABSTRAK
}

Berbicara persoalan penegak hukum adat Indonesia, memang sangat prinsipil karena adat merupakan salah satu cermin bagi bangsa, adat merupakan identitas bagi bangsa, dan identitas bagi tiap daerah. Dalam kerangka pelaksanaan Hukum Tanah Nasional dan dikarenakan tuntutan masyarakat adat maka pada tanggal 24 Juni 1999, telah diterbitkan Peraturan Menteri Negara Agraria/Kepala Badan Pertanahan Nasional (BPN) No. 5 Tahun 1999 tentang Pedoman Penyelesaian Masalah Hak Ulayat Masyarakat Hukum Adat, peraturan ini dimaksudkan untuk menyediakan pedoman dalam pengaturan dan pengambilan kebijaksanaan operasional bidang pertanahan serta langkah-langkah penyelesaian masalah yang menyangkut tanah ulayat.

Indonesia merupakan negara yang menganut pluralitas di bidang hukum, di mana diakui keberadaan hukum positif, hukum agama dan hukum adat. Dalam prakteknya (deskritif) sebagian masyarakat masih menggunakan hukum adat untuk mengelola ketertiban di lingkungannya.

Di tinjau secara preskripsi (dimana hukum adat dijadikan landasan dalam menetapkan keputusan atau peraturan perundangan), secara resmi, diakui keberadaaanya namun dibatasi dalam peranannya. Beberapa contoh terkait adalah undang-undang di bidang pertanahan (UU No. 5 th 1960) yang mengakui keberadaan hukum adat dalam kepemilikan tanah.

Kata Kunci ; Hukum Adat, Identitas Bangsa Indonesia 


\section{PENDAHULUAN}

Masyarakat madani adalah tatanan hidup kemasyarakatan dimana hubungan antara negara dan masyarakat tidak didasarkan kepada pandangan bahwa negara mempunyai kekuasaan yang sentral dan dominan dan demi kepentingannya secara sah dapat menyampingkan berbagai kepentingan warga masyarakat. ${ }^{1}$

Dalam berbagai rumusan peraturan Orde Baru kita dapat membaca bahwa negara sangat besar kekuasaannya, pandangan seperti misalnya ketentuan Undang-Undang Pokok Agraria (UUPA) Nomor 5 tahun 1960, di mana dalam salah satu pasalnya memuat tentang keberadaan hukum adat " hak atas tanah berdasarkan hukum adat diakui, sepanjang masih hidup dan tidak bertentangan dengan pembangunan”. Disini kita melihat kekuasaan yang mutlak dari negara, karena berdasarkan interpretasinya hak ulayat yang telah lama dimiliki oleh masyarakat adat, dapat dihapuskannya. ${ }^{2}$

Sebaliknya pada masyarakat madani, masyarakat yang diakui sebagai suatu entitas yang sangat plural terdiri dari berbagai kelompok sosial, budaya, misalnya gerakan wanita, rumah tangga dll, hak-hak masyarakat akan dilindungi dan dihormati.

Jika dikaitkan dengan era sekarang ini, memang dapat disebut sebagai era kebangkitan masyarakat adat yang sudah mulai tampil dengan kekuatan yang lebih besar dan mempengaruhi kebijakan-kebijakan Pemertntah di bidang ngetolaan sumber daya alam, bahkan langkah ini sebenamya sudah terlalu jauh jika hanya sekedar menyangkut soal-soal yang bersifat teknis

\footnotetext{
${ }^{1}$ T.O. Ihromi, Peranan Lembaga-Lembaga Adat Dalam Pembangunan Daerah disajikan pada Seminar Nasional VII di Jakarta tanggal 12-15 Oktober 1999

${ }^{2}$ lbid
} 
namun mudah menyinggung hal-hal yang sangat fundamental dalam kehidupan berbangsa dan bernegara yaitu masalah "kedaulatan". ${ }^{3}$

Reformasi berasal dari dua kata yaitu "re" berarti "kembali" dan "formasi" (form) : bentuk reformasi : mengembalikan kepada bentuk semula. Keinginan untuk mereformasi hukum bukan hanya tuntutan keinginan saat ini, tapi sejak berdirinya kekuasaan Orde Baru pun ini merupakan tuntutan.

Sehubungan dengan hal itu, pada tanggat 17-22 Maret 1999 telah dilangsungkan Kongres Masyarakat Adat Nusantara di Jakarta yang dihadiri oleh wakil-wakil dari 121 suku bangsa di seluruh Nusantara. Kemudian dibentuk pula apa yang dinamakan Aliansi Masyarakat Adat Nusantara (AMAN) yang telah merumuskan berbagai deklarasi, pemyataan, program dan upayaupaya yang menyangkut pemberdayaan masyarakat adat termasuk lembaga adat. ${ }^{4}$

Di dalam Garis Besat Haluan Negara (GBHN) 1999-2004 BAB IV Sub B. Ekonomi angka ke-16 dinyatakan bahwa "Mengembangkan kebijakan pertanahan untuk meningkatkan pemanfaatan dan penggunaan tanah secara adil, transparan, dan produktif dengan mengutamakan hak-hak rakyat setempat, termasuk hak ulayat dan masyarakat adat, serta berdasarkan tata ruang wilayah yang serasi dan seimbang".

\footnotetext{
${ }^{3}$ Abdurrahman, Peranan Lembaga-Lembaga Adat Dalam Pembangunan Daerah, Seminar Hukum Nasional VII Di Jakarta, tanggal 12-15 Oktober 1999

${ }^{4}$ Ibid
} 


\section{PEMBAHASAN}

\section{A. PENGERTIAN}

Pada tahun 1660 pengertian Hukum Adat sudah pernah ditulis oleh Jalaluddin Tunsam (orang Arab yang tinggal di Aceh). "Adat" berasal dari bahasa Arab artinya "kebiasaankebiasaan dari masyarakat". Kebiasaan-kebiasaan yang dimaksud ada yang "baik" dan ada pula yang "jelek" , kebiasaan-kebiasaan itu antara lain: gotong royong, tolong-menolong, musyawarah.

Kebiasaan yang merupakan pribadi bangsa Indonesia, diawali dari "Kebudayaan Melayu Indonesia", umumnya sama seperti di Malaysia, Philipina. Kemudian Hukum Adat berbeda di tiap daerah karena pengaruh

a. Agama : Hindu, Budha, Islam, Kristen dan sebagainya

Misalnya; Pulau Jawa dan Bali dipengaruhi agama Hindu; Aceh dipengaruhi Agama Islam; Ambon, Maluku dipengaruhi agama Kristen.

b. Kerajaan seperti antara lain: Sriwijaya, Airlangga, Majapahit.

c. Masuknya bangsa-bangsa Arab, China, Eropa.

Jadi Hukum Adat adalah hukum bangsa Indonesia, baik tertulis maupun tidak. ${ }^{5}$ Kemudian pada tahun 1893, Prof. Dr. C. Snouck Hurgronje dalam bukunya yang berjudul "De Atjehers" menyebutkan istilah hukum adat sebagai "adat recht" ( bahasa Belanda) yaitu untuk memberi nama pada satu sistem pengendalian social (social control) yang hidup dalam Masyarakat Indonesia.

\footnotetext{
${ }^{5}$ Rehngena Purba, Kapita Selekta Hukum Adat, Kuliah Umum, PPS USU-Medan, 23 November 1999
} 
Dalam perundang-undangan Hindia Belanda, istilah yang digunakan untuk menunjukkan/menamakan sistem pengendalian so sial antara lain:

a. Godsdienstige wetten (Undang-undang Agama), instellingen en gebruiken (Lembagalembaga dan Kebiasaan), istilah ini terdapat dalam Pasal 75 ayat (3) RR.

b. Ouder herkomsten (Kebiasaan-kebiasaan lama/kuno), terdapat dalam Pasal 78 ayat 2 RR

c. Instellingen des volks (Lembaga-lembaga Rakyat), terdapat dalam Pasal 71 ayat (3) RR.

d. Dalam Pasal 11 AB, Volksinstellingen oleh pembuat Undang-undang untuk menunjukkan hukum yang berlaku bagi golongan Bumi Putra.

Dalam kepustakaan selain istilah-istilah tadi seringkali digunakan istilah lain misalnya :

a. Volksrecht (hukum rakyat), berasal dari Mr. Beseler

b. Maleischt Polynesisrecht, pernah digunakan oleh Prof. C. Van Vollenhoven. Istilah ini oleh van Vollenhoven dimaksudkan untuk menamakan, Hukum Indonesia yang paling asli. $^{6}$

\section{B. HUKUM ADAT DALAM UNDANG-UNDANG POKOK AGRARIA (UUPA)}

Dengan diterbitkannya Undang-Undang Pokok Agraia Nomor 5 Tahun 1960 maka dualisme hukum tanah didalam masyarakat kita secara formil telah hapus. Bahagian terbesar dari hukum Barat atas tanah dengan tegas digugurkan dan dengan tegas pula dinyatakan bahwa Hukum Adatlah yang berlaku bagi soal-soal agraria.

Pasal 5 UUPA yang menyatakan bahwa "Hukum agraria yang berlaku atas bumi, air dan ruang angkasa ialah Hukum Adat, sepanjang tidak bertentangan dengan kepentingan nasional dan negara, yang berdasarkan atas persatuan bangsa dengan sosialisme Indonesia serta aturan

\footnotetext{
${ }^{6}$ Drajen Saragih, Pengantar Hukum Adat Indonesia, Tarsito, Bandung, Cet II, hal 5-6
} 
perundangan lainnya, segala sesuatu dengan mengindahkan unsur-unsur yang bersandarkan pada hukum agama".

Penjelasan atas pasal ini berbunyi bahwa pasal ini adalah merupakan penegasan bahwa Hukum Adat dijadikan dasar dari hukum yang baru. Namun ketentuan Pasal 5 tersebut dengan penjelasannya terdapat perbedaan dalam menempatkan Hukum Adat. Pasal 5 menetapkan didalam kalimat bagian muka sendiri, bahwa Hukum Adat adalah hukum yang berlaku bagi persoalan-persoalan hukum agraria, sampai disini, tercermin dengan jelas bahwa untuk hukum agraria itu berlaku Hukum Adat mengenai tanah, artinya bahwa segala masalah hukum mengenai tanah harus diselesaikan menurut ketentuan daripada Hukum Adat mengenai tanah. ${ }^{7}$

Tetapi selanjutnya dari Pasal 5 itu menyatakan "sepanjang tidak bertentangan dengan kepentingan nasional dan negara, hukum agama", sehingga menjadi kurang mengena, ini menunjukkan pandangan terhadap kedudukan Hukum Adat berbeda dengan kalimat sebelumnya. Kalimat terakhir ini menganggap bahwa Hukum Adat tidak selalu akan sesuai dengan kepentingan nasional dan negara. Dalam hal bertentangan, maka Hukum Adat harus dikesampingkan.

Apa yang melatarbelakangi perumusan Pasal 5 tersebut tidaklah jelas tetapi dapat mengingatkan kita kepada perumusan pasal 11 AB yang menyatakan bahwa “..... maka oleh hakim-hakim Bumiputra diperlakukan peraturan-peraturan yang bersangkutan dengan agama, lembaga-lembaga dan kebiasaan dari orang-orang Bumiputra sejauh peraturan-peraturan itu tidak bertentangan dengan azas-azas umum yang diakui ". Artinya Hukum Adat yang berlaku bagi orang-orang Bumiputra, berlakunya itu dengan suatu persyaratan, yaitu bahwa aturan-aturan Hukum Adat tidak boleh bertentangan dengan azas-azas umum yang diakui. Bila terjadi hal yang demikian maka dengan sendirinya harus dikesampingkan. Pandangan yang demikian (pandangan

\footnotetext{
7 Penjelasan Undang-Undang Pokok Agraria (UUPA) Nomor 5 Tahun 1960, pasal 5
} 
Nederburg) karena Hukum Adat berlaku berkat kesabaran dari pemerintah Belanda, tanpa itu tidak mungkin ada Hukum Adat.

Tetapi menurut Prof. Dr. Moh. Koensoe, SH, bahwa Hukum Adat dijadikan alasan untuk menetukan hukum agraria ialah dikarenakan Hukum Adat itulah hukum yang menurut pendapat dari pembentuk undang-undang sebagai hukum yang sesuai dengan kesadaran hukum daripada rakyat banyak. Rakyat Indonesia sebagian terbesar tunduk pada Hukum Adat karena Hukum Adat ialah hukum yang asli yang bersifat luwes dan dinamis. ${ }^{8}$

\section{KEDUDUKAN HUKUM ADAT DALAM ERA REFORMASI}

Sebagaimana telah dikemukakan sebelumnya reformasi hukum telah dilakukan di negara kita, terlepas dari penilaian yang bernada sinis tentang hasil reformasi yang dihasilkan. Pada tanggal 4 Mei 1999 telah diundangkan Undang-Undang Nomor 4 Tahun 1999 tentang Otonomi Daerah. Dengan berlakunya Undang-undang ini dinyatakan tidak berlaku lagi dua buah Undangundang yang menjadi sendi kebijakan Pemerintah Orde Baru (Orba) yaitu :

a. UU No.5 Tahun 1974 Tentang Pokok-pokok Pemerintahan di Daerah

b. UU No.5 Tahun 1979 Tentang Pemerintahan Desa.

Sesuai dengan tuntutan reformasi maka dengan penggantian Undang-undang yang baru ini seharusnya memberikan adanya peluang untuk adanya suatu otonomi yang lebih luas dari masa sebelumnya dan lebih memperdayakan masyarakat adat dan lembaga-lembaga adat yang ada di negara kita, misalnya :
a. Runggun (lembaga kekerabatan Adat Karo),
b. Lembaga Kerapatan Adat Nagari (Minangkabau),
c. Dalihan natolu (Taput)

\footnotetext{
${ }^{8}$ Mohammad Koesnoe, Catatan-Catatan Terhadap Hukum Adat Dewasa Ini, Airlangga University Press, 1979 hal 161-167
} 


\section{d. Dan lain-lain.}

Secara konsepsional, dibanding dengan peraturan sebelumnya memang terdapat kemajuan mengenai hal ini, namun kalau kita bandingkan dengan misalnya apa yang dituntut oleh Kongres Masyarakat Adat, hasilnya belum serupa. ${ }^{9}$

Dalam pandangan Dasar Kongres Masyarakat Adat Nusantara 1999 tentang Posisi Masyarakat Adat Terhadap Negara dicantumkan satu penegasan yang sangat mendasar yang menyatakan bahwa "Kami, masyarakat Adat adalah komunitas-komunitas yang hidup berdasarkan asal usul leluhur secara terum-temurun di atas suatu wilayah adat, yang memiliki kedaulatan atas tanah dan kekayaan alam, kehidupan sosial budaya yang diatur oleh hukum adat, dan lembaga adat yang mengelola keberlangsungan kehidupan masyarakat”.

Diakui dengan jelas bahwa adanya keanekaragaman budaya Masyarakat Adat di seantero Nusantara, sebagaimana yang telah dirumuskan dalam istilah Bhineka Tunggal Ika. Tapi, kenyataannya masyarakat adat tidak memperoleh pengakuan atas kedaulatan, kehidupan Masyarakat Adat dalam Republik Indonesia mengalami penderitaan-penderitaan yang serius. Penderitaan itu pada pokoknya bersumber dari tidak diakuinya Kedaulatan Masyarakat Adat oleh Kedaulatan Negara Republik Indonesia dalam berbagai praktek penyelenggaraannya. ${ }^{10}$

Konsep penguasaan Negara atas bumi, air dan kekayaan alam yang terkandung didalamnya, telah menjadi suatu alat yang ampuh menghilangkan kedaulatan Masyarakat Adat. Seperti yang terdapat dalam ketentuan UUPA, UU Nomor 5 tahun 1967, UU Nomor 11 tahun 1967, Pemegang Hak Menguasai Negara adalah pemerintah Pusat yang pada prakteknya telah mengeluarkan keputusan-keputusan yang membuka peluang bagi terjadinya pelanggaranpelanggaran hak asasi manusia yang serius. Kongres Masyarakat Adat Nusantara ini pada

\footnotetext{
${ }^{9}$ Rosnindar Sembiring, Kedudukan Hukum Adat Di Era Reformasi, Jurnal Hukum, Univ Sumatera Utara 10 Ibid
} 
pokoknya menggugat posisi Masyarakat Adat terhadap Negara. Posisi Masyarakat Adat terhadap Negara harus ditata ulang. Pengingkaran terhadap Kedaulatan Masyarakat Adat akan dengan sendirinya melemahkan kekuasaan Negara.

Keputusan Kongres Masyarakat Adat Nomor 02/KMAN/1999 tanggal 21 Maret 1999 tentang Deklarasi Aliansi Masyarakat Adat Nusantara (AMAN) berisi : Bahwa dideklarasikan tanggal 17 Maret sebagai hari kebangkitan Masyarakat Adat Nusantara ; ${ }^{11}$

a. Adat adalah sesuatu yang bersifat luhur dan menjadi landasan kehidupan Masyarakat Adat yang utama ;

b. Adat di Nusantara ini sangat majemuk, karena itu tidak ada tempat bagi kebijakan negara yang berlaku seragam sifatnya.

c. Jauh sebelum negara berdiri, Masyarakat Adat di Nusantara telah terlebih dahulu mampu mengembangkan suatu sistem kehidupan sebagaimana yang diinginkan dan dipahami sendiri. Oleh sebab itu negara harus menghormati kedaulatan Masyarakat Adat ini.

d. Masyarakat Adat pada dasarnya terdiri dari mahluk manusia yang lain oleh sebab itu, warga Masyarakat Adat juga berhak atas kehidupan yang layak dan pantas menurut nilainilai sosial yang berlaku. Untuk itu seluruh tindakan negara yang keluar dari kepatutan kemanusiaan universal dan tidak sesuai dengan rasa keadilan yang dipahami oleh Masyarakat Adat harus segera diakhiri.

e. Atas dasar rasa kebersamaan senasib sepenanggungan, Masyarakat Adat Nusantara wajib untuk saling bahu-membahu demi terwujudnya kehidupan Masyarakat Adat yang layak dan berdaulat. Merespon tuntutan di atas pada tanggal 24 Juni 1999 telah diterbitkan

\footnotetext{
${ }^{11}$ Kongres Masyarakat Adat Nomor 02/KMAN/1999 tanggal 21 Maret 1999 tentang Deklarasi Aliansi Masyarakat Adat Nusantara (AMAN)
} 
Peraturan Menteri Negara Agraria/Kepala Badan Pertanahan Nasional Nomor 5 Tahun 1999 Tentang Pedoman Penyelesaian Masalah Hak Ulayat Masyarakat Hukum Adat. Peraturan ini memuat kebijaksanaan yang memperjelas prinsip pengakuan terhadap "hak ulayat dan hakhak yang serupa itu dari masyarakat hukum adat" sebagaimana dimaksudkan dalam Pasal 3 UUPA. Kebijaksanaan tersebut meliputi :

a. Penyamaan persepsi mengenai "hak ulayat" (Pasal 1)

b. Kriteria dan penentuan masih adanya hak ulayat dan hak-hak yang serupa dari masyarakat hukum adat (Pasal 2 dan 5).

c. Kewenangan masyarakat hukum adat terhadap tanah ulayatnya (Pasal 3 dan 4).

Maksud dikeluarkannya peraturan ini adalah untuk menyediakan pedoman dalam pengaturan dan pengambilan kebijaksanaan operasional bidang pertanahan serta langkah-langkah penyelesaian masalah yang menyangkut tanah ulayat, dalam kerangka pelaksanaan Hukum Tanah Nasional.

Pengaturan lebih lanjut mengenai hal-hal di atas diwenangkan kepada Daerah menurut peraturan perundang-undangan yang berlaku (Pasal 6) sesuai dengan maksud UU Nomor 22 Tahun 1999 Tentang Pemerintahan Daerah dan dengan demikian akan lebih mampu menyerap aspirasi masyarakat setempat.

Apabila kita simak jiwa dan makna yang terkandung dalam UU Nomor 22 Tahun 1999 ini khususnya tentang pengertian "Desa" secara utuh, maka merupakan suatu beban dalam mengkaji secara cermat tentang hak asal-usul dan susunan asli suatu desa, kesatuan masyarakat hukum pendatangnya serta sejauh mana organisasi masyarakat hukum ini masih etis serta kewenangannya. ${ }^{12}$

\footnotetext{
${ }^{12}$ Rehngena Purba, Sejarah Asal Usul Desa Serta Masyarakat Hukum Adat, Study Kasus Di Kabupaten Karo Rumah Kabanjahe, Kecamatan Kabanjahe, 1999
} 
Kata-kata "susunan asli suatu desa" mengingatkan kita pada orasi van Vollenhoven pada tanggal 2 Oktober 1901 yang menegaskan, bahwa untuk mengetahui hukum maka terutama perlu diselidiki pada waktu apapun dan di daerah mana juga pun, sifat dan susunan badan-badan persekutuan hukum (baca masyarakat hukum), dimana orang-orang yang dikuasai oleh hukum itu hidup sehari-hari. ${ }^{13}$ Sebagai gambaran, maka masyarakat adat yaitu :
a. Masyarakat Hukum Territorial
b. Masyarakat Hukum Genealogis
c. Masyarakat Hukum Territorial-Genealogis
d. Masyarakat Hukum Adat -Keagamaan
e. Masyarakat Hukum Adat di Perantauan
f. Dll.

Sedangkan menurut Ter Haar (1960:16), masyarakat hukum adalah : "Kelompokkelompok masyarakat yang tetap dan teratur dengan mempunyai kekuasaan sendiri dan kekayaan sendiri baik berwujud atau tidak berwujud". ${ }^{14}$ Dan bila dikaitkan dengan tiang-tiang yang ditegakkan oleh van Vollenhoven ada 7 antara lain persekutuan hukum (tiang pertama), hak ulayat (tiang kedua). ${ }^{15}$

\section{KESIMPULAN}

Hukum Adat adalah hukum yang benar-benar hidup dalam kesadaran hati nurani warga masyarakat yang tercermin dalam pola-pola tindakan mereka sesuai dengan adat-istiadatnya dan pola sosial budayanya yang tidak bertentangan dengan kepentingan nasional.

\footnotetext{
${ }^{13}$ Soerojo.W, Pengantar dan Asas-Asas Hukum Adat, PT Gunung Agung, Bandung, 1984, hal 77

${ }^{14}$ Hilman. H, Pengantar Ilmu Hukum Adat Indonesia, Mandar Maju, Bandung, 1992, hal 105

${ }^{15}$ Mahadi, Uraian Singkat Tentang Hukum Adat, Alumni, Bandung, 1991, hal 104
} 
Era sekarang memang dapat disebut sebagai era kebangkitan masyarakat adat yang ditandai dengan lahirnya berbagai kebijaksanaan maupun keputusan Pengadilan. Namun yang tak kalah penting adalah perlu pengkajian dan pengembangan lebih jauh dengan implikasinya dalam penyusunan hukum nasional dan upaya penegakan hukum yang berlaku di Indonesia.

\section{DAFTAR PUSTAKA}

Abdurrahman, Peranan Lembaga-Lembaga Adat Dalam Pembangunan Daerah, Seminar Hukum Nasional VII, Jakarta, 12 s/d 15 Oktober 1999.

Djaren Saragih, Pengantar Hukum Adat Indonesia Edisi II, Tarsito, Bandung, 1984.

Hilman H, Pengantar Ilmu Hukum Adat Indonesia, Mandar Maju, Bandung, 1992.

Mahadi, Uraian Singkat Tentang Hukum Adat, Alumni, Bandung. 1991.

Moh. Koesnoe, Catatan-Catatan Terhadap Hukum Adat Dewasa Ini, Airlangga University Press, 1979

Rehngena Purba, Laporan Hasil Penelitian Sejarah Asal-Usul Desa Serta Masyarakat Hukum Adat (Studi Kasus di Kabupaten Karo Rumah Kabanjahe Kec. Kabanjahe), 1999.

Rosnindar Sembiring, Kedudukan Hukum Adat Di Era Reformasi, Jurnal Hukum, Univ Sumatera Utara

Soerjo W, Pengantardan Asas-asas Hukum Adat, P.T. Gunung Agung, 1984.

T.O. Ihroni, Peranan Lembaga-Lembaga Adat Dalam Pembangunan Daerah, Seminar Hukum Nasional VII, Jakarta, 12 s/d 15 Oktober 1999.

Undang-Undang Pokok Agraria Nomor 5 Tahun 1960. 